\title{
Preventive Phytotherapy of Anaphylaxis and Allergic Reactions
}

\author{
Elaine A. Cruz ${ }^{1}$, Michelle F. Muzitano1, \\ Sonia S. Costa ${ }^{2}$ and Bartira Rossi-Bergmann ${ }^{3}$ \\ ${ }^{1}$ Faculdade de Farmacia, Macae Campus, \\ ${ }^{2}$ Nucleo de Pesquisa de Produtos Naturais, \\ Instituto de Biofisica Carlos Chagas Filho, \\ Universidade Federal do Rio de Janeiro,
}

Brazil

\section{Introduction}

Anaphylactic shock is an extreme and life-threatening allergic reaction that requires immediate action to prevent death from airway and blood pressure collapse. The acute management comprises the use of epinephrine (adrenaline), the first-line medication of choice, and H1-antihistaminic drugs in doses that will depend on the severity of symptoms, in order to preserve the airway function and maintain the blood pressure and oxygenation at acceptable levels (Kemp \& Lockey, 2002). On the other hand, long-term management comprises identification of precipitants (e.g.: Medications, foods, latex, insect venom) and their avoidance, and also immunotherapy.

One of the main mediators that are released and associated the many anaphylactic symptoms is histamine. H1-antihistamines are commonly used to relieve anaphylactic cutaneous symptoms such as itching, flushing, and urticaria, but play little role in the relief of bronchospasm or gastrointestinal symptoms, and fail to relieve upper airway edema or hypotension. Moreover, in usual doses, antihistamines alone do not prevent the explosive release of histamine and other mediators of inflammation from mast cells and basophils that culminate in the anaphylactic shock.

Since bronchospasm, hypotension and edema are not reversed immediately with antihistamines, a rapid administration of epinephrine is required to revert these symptoms. It has potent life-saving $\beta-1$ adrenergic vasoconstrictor effects on the small arterioles and precapillary sphincters leading to decreased mucosal edema, thereby preventing and relieving upper airway obstruction, and also to increased blood pressure, thereby preventing and relieving shock. (Kemp et al, 2008). Its strong effect on $\beta-1$ adrenergic receptors activation lead to increased rate and force of cardiac contractions, while activation of $\beta-2$ adrenergic receptors leads to increased bronchodilation and decreased release of histamine, tryptase, and other mediators of inflammation from mast cells and basophils (T.C. Westfall \& D.P. Westfall, 2006). The adverse effects of epinephrine therapy involve pallor, headache $(\beta-1$ adrenergic receptors), palpitations ( $\beta-1$ adrenergic receptors), tremor, vasodilation, increased release of mediators ( $\beta-2$ adrenergic receptors) and anxiety (central CNS stimulation) that altogether 
may impose severe risk to patients with cardiac, central nervous system or thyroid diseases. On the other hand, glucocorticoids, that down-regulate $\beta$ - 2 while up-regulating $\beta-1$ adrenergic receptors and are mainstays in the treatment of asthma, have been shown not to reverse anaphylaxis symptoms (Simons, 2006). Therefore, in view of the hyper-acute nature of anaphylactic shock that limits adequate therapy, prevention is still the most adequate measure. Current prevention of anaphylaxis is based on allergen desensitization through specific immunotherapy of patients with high-risk of type I hypersensitivity reactions that involve immunoglobulin E (IgE)-mediated release of histamine and other mediators. The immunotherapy comprises the administration of increased doses of low-concentrated specific allergen solution that induce peripheral tolerance associated with differentiation of IL-10 and TGF- $\beta$ - producing CD4 ${ }^{+} C D 25^{+}$regulatory T cells (Francis et al , 2003; Jutel et al, 2003). The efficacy of immunotherapy is also associated with an increase of antigen-specific IgG antibodies that block IgE effects on mast cells and basophils (Akdis \& Blaser, 2000). Table 1 summarizes the current measures available to treat and prevent anaphylactic shock:

\begin{tabular}{|c|c|c|}
\hline DRUG & $\begin{array}{l}\text { PHASE OF } \\
\text { MANAGEMENT }\end{array}$ & EFFECTS \\
\hline EPINEFRINE & Acute & $\begin{array}{l}\text { Vasoconstriction, increased peripheral } \\
\text { vascular resistance, increased blood } \\
\text { pressure and relief of hypotension and } \\
\text { shock; decreased mucosal edema and } \\
\text { relief of upper airway obstruction and } \\
\text { angioedema (effects through } \beta-1 \\
\text { adrenergic receptors). Bronchodilation, } \\
\text { decreased release of mediators (effects } \\
\text { through } \beta-2 \text { adrenergic receptors). }\end{array}$ \\
\hline H1-ANTIHISTAMINES & Acute & $\begin{array}{l}\text { Relief of itching, flushing, urticaria, } \\
\text { bronchospasm and gastrointestinal } \\
\text { symptoms. }\end{array}$ \\
\hline $\begin{array}{l}\beta 2 \text {-ADRENERGIC } \\
\text { AGONIST }\end{array}$ & Acute & $\begin{array}{l}\text { Reversion of bronchospasm by relaxing } \\
\text { of airway smooth muscle and reduction } \\
\text { of asphyxia. }\end{array}$ \\
\hline GLUCOCORTICOIDS & Acute & $\begin{array}{l}\text { Inhibition of cytokine and arachidonic } \\
\text { acid derivates production. }\end{array}$ \\
\hline IMMUNOTHERAPY & Long-term & $\begin{array}{l}\text { Induction of antigen-specific tolerance } \\
\text { and increase of blockers antigen-specific } \\
\text { IgG antibodies production. }\end{array}$ \\
\hline
\end{tabular}

Table 1. Summary of management of anaphylactic shock

\section{Plants as sources of anti-allergic substances}

Over the years, ethnobotanical studies allowed the association of plants with a diversity of biological activities and the discovery of new pharmaceutical drugs (Farnsworth et al., 1994). In the period 1981 to 2006, 52\% of the small molecules discovered and in the development process were natural products or had their origins in natural products (Newman et al., 2007). 
There have been many reports on the anti-allergic effects of some plants and natural compounds (Table 2).

\begin{tabular}{|c|c|c|c|c|}
\hline SPECIES & EXTRACT & $\begin{array}{l}\text { EXPERIMENTAL } \\
\text { MODEL }\end{array}$ & EFFECT & REFERENCE \\
\hline $\begin{array}{l}\text { Ailanthus } \\
\text { altissima }\end{array}$ & Swingle & Rat & $\begin{array}{l}\text { Inhibits production of } \\
\text { histamine, TNF, IL-6, and } \\
\text { IL-8, and nuclear NF- } \\
\kappa B / \text { Rel A }\end{array}$ & Kang et al., 2010 \\
\hline $\begin{array}{l}\text { Albizzia } \\
\text { lebbeck }\end{array}$ & $\begin{array}{l}\text { Bark aqueous } \\
\text { extract }\end{array}$ & Guinea pig & $\begin{array}{l}\text { Inhibits ileum contraction } \\
\text { and bronchospasm }\end{array}$ & Barua et al.,1997 \\
\hline $\begin{array}{l}\text { Baliospermu } \\
\text { m montanum }\end{array}$ & $\begin{array}{l}\text { Leaf } \\
\text { chloroform and } \\
\text { ethanol } \\
\text { extracts }\end{array}$ & Rat & $\begin{array}{l}\text { Inhibits mast cell } \\
\text { degranulation }\end{array}$ & $\begin{array}{l}\text { Venkatesh et al., } \\
2010\end{array}$ \\
\hline $\begin{array}{l}\text { Calotropis } \\
\text { gigantea }\end{array}$ & $\begin{array}{l}\text { Methanol } \\
\text { extract }\end{array}$ & Rat & Inhibits paw edema & $\begin{array}{l}\text { Ghaisas et al., } \\
2011\end{array}$ \\
\hline $\begin{array}{l}\text { Camellia } \\
\text { japonica }\end{array}$ & $\begin{array}{l}\text { Leaf extract. } \\
\text { (quercetin and } \\
\text { eugenol) }\end{array}$ & Rat & $\begin{array}{l}\text { Inhibits Src-family kinase } \\
\text { and degranulation in mast } \\
\text { cells, and passive } \\
\text { cutaneous anaphylaxis. }\end{array}$ & Lee et al., 2008 \\
\hline $\begin{array}{l}\text { Crinum } \\
\text { glaucum }\end{array}$ & $\begin{array}{l}\text { Aqueous } \\
\text { extract }\end{array}$ & Guinea pig & Inhibits ileum contractions & $\begin{array}{l}\text { Okpo and } \\
\text { Adeyemi, } 2002\end{array}$ \\
\hline $\begin{array}{l}\text { Euphorbia } \\
\text { hirta }\end{array}$ & Ethanol extract & Rat and mouse & $\begin{array}{l}\text { Inhibits paw edema, } \\
\text { passive cutaneous and } \\
\text { systemic anaphylaxis, } \\
\text { TNF-a and IL-6. }\end{array}$ & $\begin{array}{l}\text { Youssouf et } \\
\text { al.,2007 }\end{array}$ \\
\hline $\begin{array}{l}\text { Garcinia } \\
\text { brasiliensis }\end{array}$ & $\begin{array}{l}\text { 7- } \\
\text { epiclusianone }\end{array}$ & Guinea pig & $\begin{array}{l}\text { Inhibits allergen-evoked } \\
\text { intestinal spasm }\end{array}$ & Neves et al., 2007 \\
\hline $\begin{array}{l}\text { Impatiens } \\
\text { balsamina }\end{array}$ & $\begin{array}{l}\text { Petal ethanol } \\
\text { extract } \\
\text { (flavonols and } \\
\text { naphthoquinon } \\
\text { es) }\end{array}$ & Mouse & $\begin{array}{l}\text { Prevents blood pressure } \\
\text { fall and } \\
\text { fatal anaphylactic shock }\end{array}$ & $\begin{array}{l}\text { Ishiguro et } \\
\text { al.,1997; } \\
\text { Fukumoto et } \\
\text { al.,1996 }\end{array}$ \\
\hline $\begin{array}{l}\text { Impatiens } \\
\text { textori }\end{array}$ & $\begin{array}{l}\text { Flower ethanol } \\
\text { extract } \\
\text { (apigenin, and } \\
\text { luteolin) }\end{array}$ & Mouse & $\begin{array}{l}\text { Inhibits scratching } \\
\text { behavior and blood } \\
\text { pressure decrease. }\end{array}$ & Ueda et al., 2005 \\
\hline $\begin{array}{l}\text { Kalanchoe } \\
\text { pinnata }\end{array}$ & $\begin{array}{l}\text { Aqueous } \\
\text { extract } \\
\text { (quercitrin) }\end{array}$ & Mouse & $\begin{array}{l}\text { Inhibits bronchospasm, } \\
\text { fatal anaphylactic shock, } \\
\text { IgE, eosinophilia, IL-5, IL- } \\
\text { 10, IL-13 and TNF-a, and } \\
\text { histamine release. }\end{array}$ & $\begin{array}{l}\text { Cruz et al, 2011, } \\
\text { Cruz et al., } 2008\end{array}$ \\
\hline $\begin{array}{l}\text { Macrocystis } \\
\text { pyrifera } \\
\text { seaweed }\end{array}$ & Alginic acid & Rat & $\begin{array}{l}\text { Inhibits histamine release, } \\
\text { IL- } 1 \beta \text { and TNF- } \alpha \text {, but not } \\
\text { IL- } 6 \text { or IL- } 8 \text { production. }\end{array}$ & Jeong et al., 2006 \\
\hline
\end{tabular}




\begin{tabular}{|c|c|c|c|c|}
\hline SPECIES & EXTRACT & $\begin{array}{l}\text { EXPERIMENTAL } \\
\text { MODEL }\end{array}$ & EFFECT & REFERENCE \\
\hline $\begin{array}{l}\text { Matricaria } \\
\text { recutita }\end{array}$ & $\begin{array}{l}\text { Methanol } \\
\text { extract }\end{array}$ & Rat & $\begin{array}{l}\text { Reduces compound } 48 / 80 \\
\text { induced anaphylaxis and } \\
\text { histamine release }\end{array}$ & $\begin{array}{l}\text { Chandrashekhar } \\
\text { et al., } 2011\end{array}$ \\
\hline Oryza sativa & $\begin{array}{l}\text { Methanol } \\
\text { extract }\end{array}$ & Rat & Reduces histamine release & Kim et al., 1999 \\
\hline $\begin{array}{l}\text { Picrorhiza } \\
\text { kurroa }\end{array}$ & $\begin{array}{l}\text { Root and } \\
\text { rhizome } \\
\text { glycoside } \\
\text { fraction }\end{array}$ & $\begin{array}{l}\text { Guinea pig, mouse } \\
\text { and rat. }\end{array}$ & $\begin{array}{l}\text { Inhibits passive cutaneous } \\
\text { anaphylaxis, ileum } \\
\text { contraction but not } \\
\text { bronchospasm induced by } \\
\text { histamine. }\end{array}$ & $\begin{array}{l}\text { Baruah et al., } \\
1998\end{array}$ \\
\hline $\begin{array}{l}\text { Porcirus } \\
\text { trifoliata }\end{array}$ & $\begin{array}{l}\text { Aqueous } \\
\text { extract }\end{array}$ & Rat & Inhibits histamine release & Lee et al., 1996 \\
\hline $\begin{array}{l}\text { Prunus } \\
\text { mahaleb }\end{array}$ & $\begin{array}{l}\text { Ethanol extract } \\
\text { (oleic and } \\
\text { linoleic acids) }\end{array}$ & Guinea pigs & $\begin{array}{l}\text { Ovalbumin-induced } \\
\text { bronchospasm }\end{array}$ & Shams et al., 2007 \\
\hline $\begin{array}{l}\text { Rhus } \\
\text { javanica }\end{array}$ & $\begin{array}{l}\text { Gall aqueous } \\
\text { extract }\end{array}$ & Rat and mouse & $\begin{array}{l}\text { Decrease histamine release, } \\
\text { TNF- } a \text { and IL-6 secretion. }\end{array}$ & Kim et al., 2005 \\
\hline
\end{tabular}

Table 2. Anti-anaphylactic natural products

Chamomile (Matricaria recutita, Asteraceae) is one of the medicinal plants whose methanol extract containing flavonoids, tannins, terpenoids and coumarines has reported properties against compound 48/80 induced anaphylaxis in rats (Chandrashekhar et al., 2011). Not only plants but also seaweeds containing alginic acid (Jeong et al., 2006) and honeybeesproduced propolis have been marketed for their anticipated anti-allergic effects (revised by Sforcin, 2007). Propolis consists of approximately 300 plant-derived compounds including flavonoids, phenolic acids, cinnamic acid derivatives, terpenoids, cellulose and amino acids. It has demonstrated protection against OVA-sensitized airway inflammatory reaction associated with inihibition of mast cell degranulation, and chrysin and kaempferol present in the ethanol extract appears to be the main anti-allergic compounds (Nakamura et al., 2010). Since 2005, there have been a number of double-blind, placebo-controlled clinical studies in China investigating the efficacy and safety of Chinese herbal products. The major findings of four promising herbal remedies, comprising at least three plant species, were revised by Li and Brown (2009).

Most of the plant products that fight inflammation belong to the chemical groups of alkaloids, coumarins, polyphenols, terpenoids and flavonoids. In particular, flavonoids such as quercetin, luteolin, fisetin and apigenin have been described with potent immunomodulatory properties. Studies on structure-activity relationship of 45 flavonoids showed that oberall they were more potent in inhibiting the production of IL- 4 which is largely associated with allergic reactions (Revised by Kawai et al. 2007). Comalada et al. (2006) studied the structure-activity relationship for several flavonoids using primary bone marrow-derived mouse macrophages. They observed that some flavonoids inhibit TNF- $\alpha$ production as well as $i$ NOS expression and nitric oxide (NO) production in LPS-activated macrophages, an effect that has been associated with the inhibition of the NF- $\kappa B$ pathway. 
Suppression of of NF- $\mathrm{B}$ nuclear factor activation by Ailanthus altissima swingle has also been associated with the reduced production of TNF-a, IL-6, and IL-8 pro-inflammatory cytokines and reduced histamine release during induced anaphylaxis (Kang et al., 2010). Flavonoids are known to have potent antiallergic activity (Kawai et al, 2007). For instance, luteolin and quercetin flavonoids (Figure 1) are potent inducers of the anti-inflammatory cytokine IL-10. Structure-activity relationship showed that four hydroxylations at positions $5,7,30$ and 40, together with the double bond at C2-C3 and the position of the B ring at 2, seem to be necessary for the highest anti-inflammatory effect.<smiles>O=c1c(O)c(-c2ccc(O)c(O)c2)oc2cc(O)cc(O)c12</smiles>

Quercetin<smiles>O=c1cc(-c2ccc(O)c(O)c2)oc2cc(O)cc(O)c12</smiles>

\section{Luteolin}

Fig. 1. Chemical structures of quercetin and luteolin flavonoids.

Due to the problematic curative therapeutics, preventive therapy may be an alternative life-saving therapy in highly allergic individuals prone to anaphylactic shock. It depends primarily on optimal management of risk factors, avoidance of allergen and other anaphylactic sensitizers (food, insect stings, plants and drugs), and immunomodulation. Since induced immunotolerance therapy involving the administration of increasing doses of a specific allergen has had limited success, and currently available immunosuppressive drugs are not safe enough to be continuously administered as a prophylactic measure, new anti-anaphylactic substances are highly needed in the market. In view of the enormous diversity of chemicals produced, medicinal plants are particularly interesting for the discovery of new anti-allergic agents as the safety of continuous consumption (e.g. herbal infusions) is popularly testified. This is the case of the plant Kalanchoe pinnata, whose potential use as source of anti-anaphylactic substances is described below in more detail.

\section{The Kalanchoe pinnata example}

Kalanchoe pinnata (Kp, syn Bryophyllum pinnatum Kentz., Bryophyllum calycinum Salisb., Crassulaceae) (Figure 2), is widely used in folk medicine in the form of infusions, juices and compresses to treat rheumatoid arthritis, gastric ulcer and in skin disorders (Lucas and Machado, 1946; Lorenzi and Abreu-Matos, 2008). It is native of Madagascar, Kp is now found in several countries such as India, China, and Brazil (Allorge-Boiteau, 1996). 

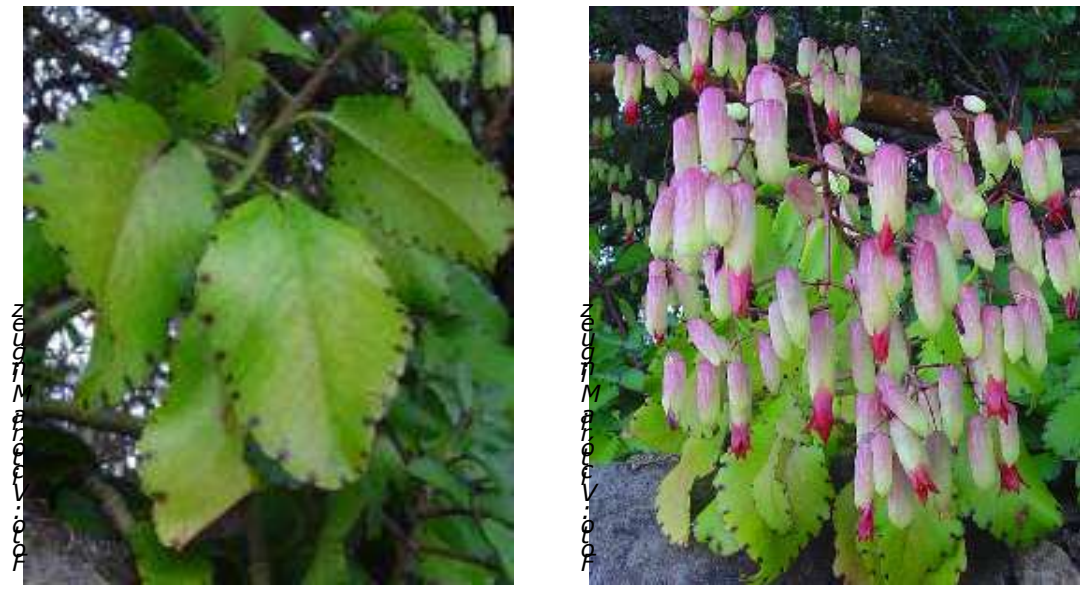

Fig. 2. Kalanchoe pinnata (Crassulaceae) : Leaves and Inflorescences

Antiparasitic (anti-leishmania), antibacterial, hepatoprotective and immunomodulatory activities have been described for Kp leaf extracts (Da Silva et al. 1995; Akinpelu, 2000; Muñoz et al. 2000; Yadav and Dixit, 2003; Rossi-Bergmann et al. 1994; Almeida et al., 2000). Exploratory toxicological studies in mice and humans have indicated absence of chronic and acute oral toxicity (Torres-Santos et al., 2003, Sousa et al., 2005). The clinical safety of Kp was also suggested during a study in 67 pregnant women ( 25 to 35 weeks of gestation) and their neonates (Plangger et al., 2006), corroborating its popular acceptance and pharmaceutical potential.

$\mathrm{Kp}$ contains substances belonging to different chemical classes, including: terpenes (Siddiqui et al. 1989; Gaind et al., 1972), bufadienolidos (Yamagishi et al., 1989; Supratman et al., 2001) and flavonoids (Gaind and Gupta, 1971; Ichikawa, 1986; Muzitano et al., 2006a, 2006b and 2009). Kp flavonoids are significantly more abundant when the leaves are collected during the summer (Muzitano et al., 2011). Quercitrin (quercetin 3-O- $\alpha-\mathrm{L}-$ rhamnopyranoside), kaempferol 3-O- $\alpha$-L-arabinopyranosyl $(1 \rightarrow 2)$ - $\alpha$-L-rhamnopyranoside (kapinnatoside), quercetin 3-O- $\alpha$-L-arabinopyranosyl $(1 \rightarrow 2)-\alpha$-L-rhamnopyranoside and $4^{\prime}, 5$-dihydroxy-3',8-dimethoxyflavone 7-O- $\beta$-D-glucopyranoside were isolated from a bioactive flavonoid fraction obtained from a Kp aqueous extract (Muzitano et al., 2006a, 2006b and 2009).

\subsection{The anti-anaphylactic effect of the aqueous extract of Kalanchoe pinnata}

The anti-anaphylactic activity of the aqueous extract of Kp leaves given orally to ovalbumin (OVA)-sensitized mice indicated the potent immunomodulatory action, preferentially inhibiting Th2-type immune responses known to be committed with enhanced susceptibility to cutaneous leishmaniasis and to allergies (Rossi-Bergmann et al, 1994; Da Silva et al 1999, Cruz et al 2008, Gomes et al 2009). Despite the early reports on the antihistaminic activity of $\mathrm{Kp}$ using the experimental models of isolated guinea pig ileum contraction and vasodilatation in rats (Nassis et al, 1992); its fatty acid associated suppressive activity on T cells (Rossi-Bergmann et al, 1994, Almeida et al, 2000).), and its Th2-suppressive and iNOSsuppressive association with oral protection against cutaneous and visceral leishmaniasis 
(Da-Silva et al, 1995, Da-Silva et al, 1999, Gomes et al. 2009), only recently the therapeutic effect of Kp in allergy was more deeply explored.

The antianaphylactic activity o Kp was studied using a murine model of OVA-induced anaphylactic shock. The intraplantar injection of OVA $(2.5 \mathrm{mg} / \mathrm{kg})$ into pre-sensitised mice elicited a severe systemic anaphylactic response with death occurring within 15 min-30 min of allergen challenge. This extreme allergic reaction was effectively prevented with 400 $\mathrm{mg} / \mathrm{Kg}$ of oral $\mathrm{Kp}$ during the 14-day sensitization process that maintained alive $100 \%$ for over $48 \mathrm{~h}$ of follow-up. Intraperitoneal injections with $200 \mathrm{mg} / \mathrm{kg}$ of $\mathrm{Kp}$ every other day during the same period of time was also effective, but to a lesser extent ( $80 \%$ of survival), similar to observed with $12.5 \mathrm{mg} / \mathrm{Kg}$ of i.p. cyclosporin $\mathrm{A}$, an immunosuppressive drug also having anti-allergic effect. Interestingly, a single i.p. dose of $200 \mathrm{mg} / \mathrm{Kg}$ of $\mathrm{Kp} 3 \mathrm{~h}$ prior to OVA challenge was sufficient to protect $60 \%$ of the animals, suggesting that not only immunosuppression but also modulation of acute events related to shock was critical for protection.

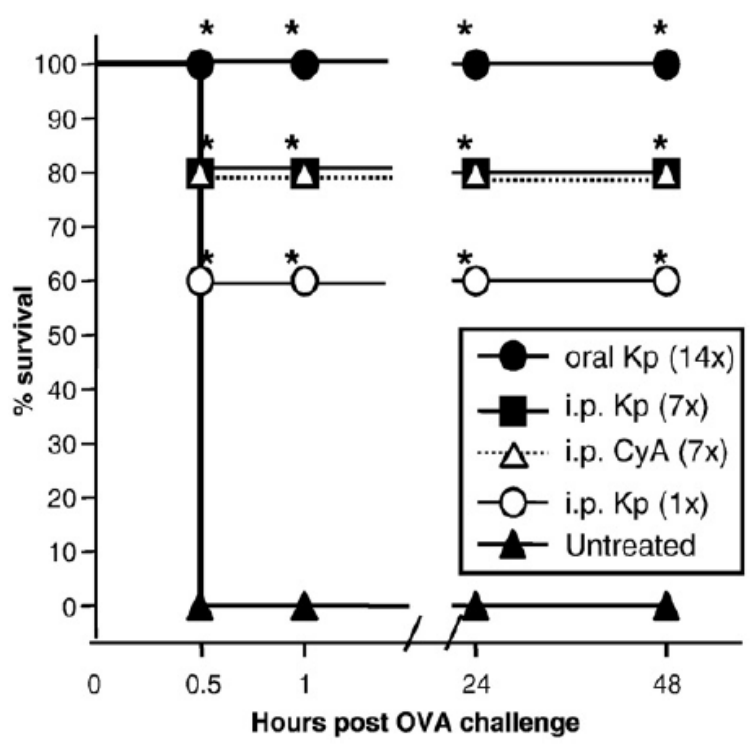

Fig. 3. Pre-treatment with Kp prevents fatal anaphylactic shock. BALB/c mice $(n=5)$ were sensitized with OVA in adjuvant on days 1 and 7, and were challenged with $50 \mu \mathrm{g}$ of OVA on day 14. During the sensitization period, they were treated as follows: i) by the oral route (daily doses of $400 \mathrm{mg} / \mathrm{Kg}$ of $\mathrm{Kp}$ for 14 days), ii) by the intraperitoneal route (7 doses of 200 $\mathrm{mg} / \mathrm{Kg}$ of $\mathrm{Kp}$ or $12.5 \mathrm{mg} / \mathrm{Kg}$ of Cyclosporin in alternate days; or a single dose of 200 $\mathrm{mg} / \mathrm{Kg}$ of Kp $3 \mathrm{~h}$ before OVA challenge). Controls were left untreated. Upon challenge on day 14 , death events were monitored for up to $48 \mathrm{~h}$ and recorded as shown. The results are expressed as the percentage of surviving animals. ${ }^{*} \mathrm{p}<0.01$ compared to untreated group.

As allergic parameters, the effect of $\mathrm{Kp}$ treatment on the number of circulating eosinophils and in allergen-specific IgE response was investigated. The OVA-induced enhanced eosinophilia was prevented by $\mathrm{Kp}$, especially in animals receiving multiple oral or i.p. doses, although a single i.p. dose of Kp could be effective (Figure 4A). The raised production 
of OVA-specific IgE in sensitized mice was prevented by Kp therapy, particularly in animals on the oral regimen (Figure $4 \mathrm{~B}$ ).
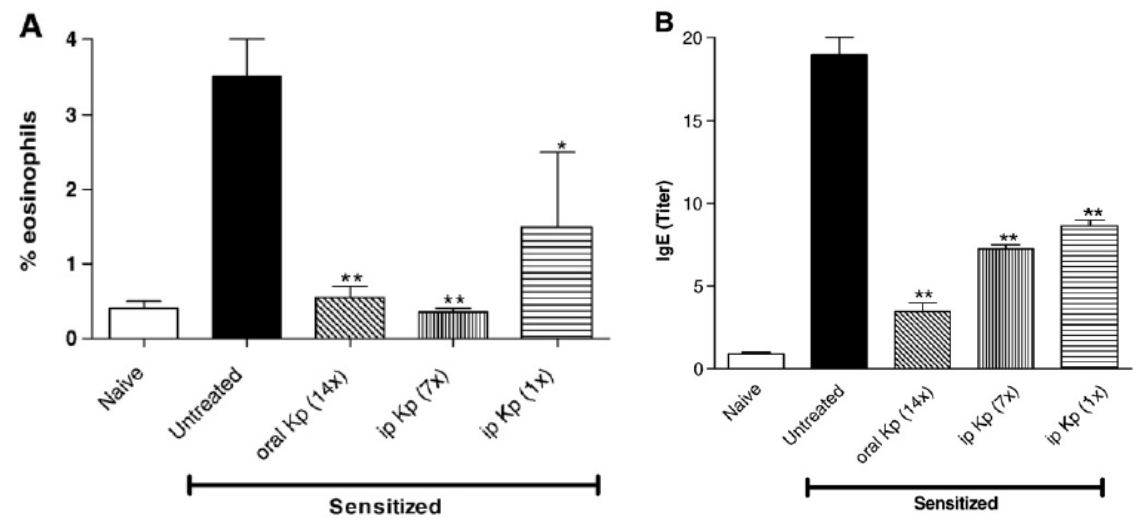

Fig. 4. Decreased eosinophilia and OVA-specific IgE levels in Kp-treated mice. Mice were sensitized and treated with Kp as for Fig. 1. A group of animals was bled $1 \mathrm{~h}$ before allergen challenge for the percentage of eosinophils in total leukocytes (top) and for individual assessment of the serum levels of anti-OVA IgE (bottom). Means $\pm S . D(n=4) .{ }^{*} p \leq 0.05$ and ${ }^{* *} \mathrm{p} \leq 0.01$ in relation to untreated controls.

\subsection{Quercitrin as an important anti-anaphylactic component of Kalanchoe pinnata}

Like the aqueous extract, the isolated quercitrin flavonoid (Figure 5) was found to to be active in mice against cutaneous leishmaniasis caused by Leishmania amazonensis infection (Muzitano et al, 2006). Since cutaneous leishmaniasis, like allergy, is a disease driven by Th2-type immune responses, quercitrin was tested in the mouse model of OVA-induced anaphylactic shock. The animals were treated daily with oral quercitrin during the 14-day OVA-sensitization, with a dose $5 \%$ of that used with $\mathrm{Kp}(400 \mathrm{mg} / \mathrm{Kg})$, compatible with its content in the aqueous extract. We observed that oral treatment with quercitrin conferred resistance to fatal anaphylactic shock in $75 \%$ of the animals, as compared with $0 \%$ of resistance in untreated sensitized animals (Figure 6), suggesting that quercitrin is an important anti-anaphylactic component of Kp.<smiles>[R]c1c(-c2ccc(O)c(O)c2)oc2cc(O)cc(O)c2c1=O</smiles>

Quercitrin: $\mathrm{R}=\mathrm{O}-\mathrm{a}-$-ramnopyranose

Fig. 5. Chemical structure of quercitrin. 
To better analyze the modulatory effect on Th2-type T cells, IL-5 and IL-10 cytokines were measured in the cell culture supernatants. Treatment of sensitized mice with oral or i.p. Kp reduced the capacity of their cells to respond to OVA with IL-5 and IL-10 production (Fig. 7). The production of TNF-a was also inhibited by Kp treatment, and like IL-10, this effect was more pronounced when the i.p. route was used, indicating that cytokines that contribute to allergy are down regulated during i.p, and to a lesser extent oral $\mathrm{Kp}$ treatments. The importance of the TNF- $\alpha$ was confirmed in mice deficient in TNFR1, and corroborated with other studies on Ailanthus altissimain and Euphorbia hirta (Table 2).

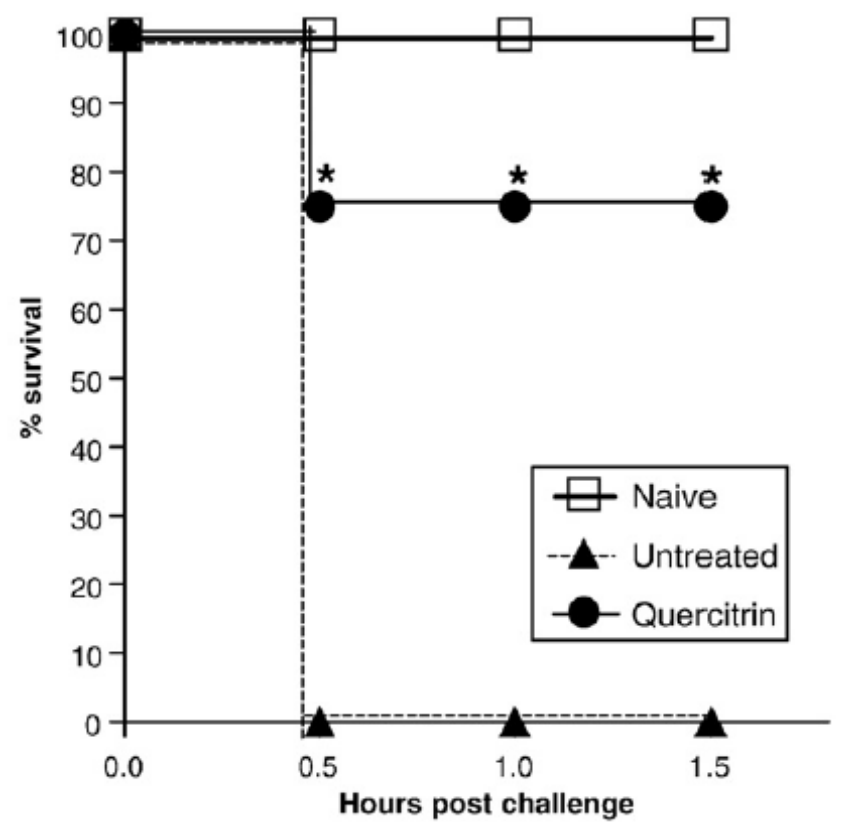

Fig. 6. Pre-treatment with quercitrin partially prevents death due to anaphylactic shock.

BALB/c mice $(n=8)$ were sensitized as for Fig. 1 . During the sensitization period, they were daily treated with $20 \mathrm{mg} / \mathrm{Kg}$ of quercitrin by the oral route, during 14 days. Controls were left untreated. Naive were untreated non-immunized mice. Upon challenge on day 14, death events were monitored for up to $90 \mathrm{~min}$ and recorded as shown. The results are expressed as the percentage of surviving animals. *pb0.01 compared to untreated group.

The effect of Kp on histamine release by anti-DNP IgE-sensitized mast cells challenged with DNP was also investigated, and a significant inhibition of secreted histamine was found in cells that were pre-treated with Kp prior to DNP challenge (Fig. 8).

As mentioned above, cutaneous leishmaniasis and allergy are pathologies associated with expanded Th2-type immune responses, and they are benefited from the oral treatment with $\mathrm{Kp}$. Although blockade of histamine release may ultimately contribute to the antianaphylactic effect of $\mathrm{Kp}$, it is conceivable that downregulation of Th2-type immune responses is more critical for the resistance phenotype. The immunological effects of Kp are summarized in Figure 9. 

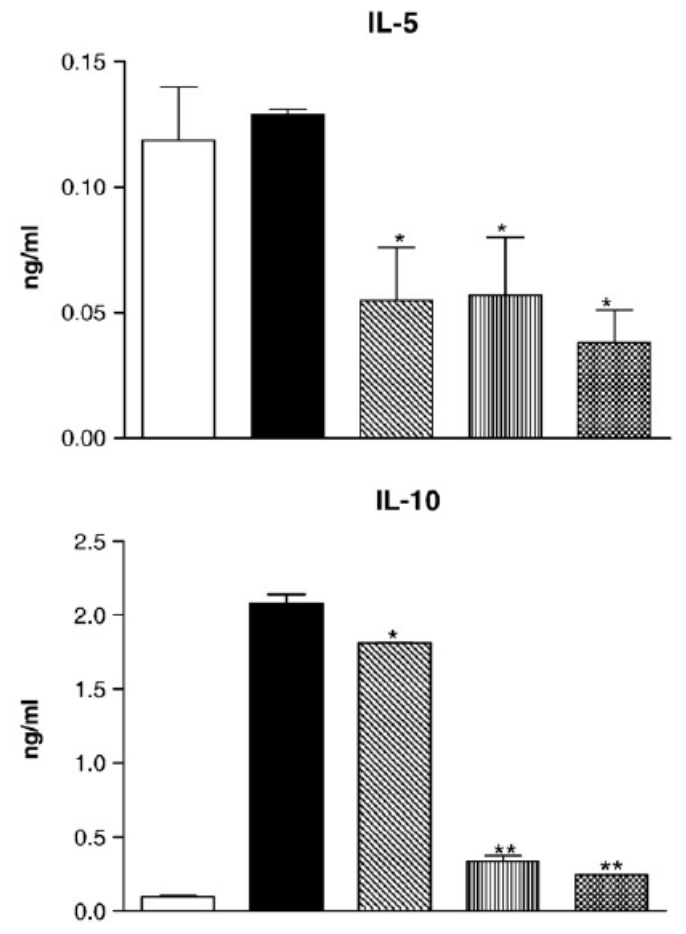

TNF- $\alpha$

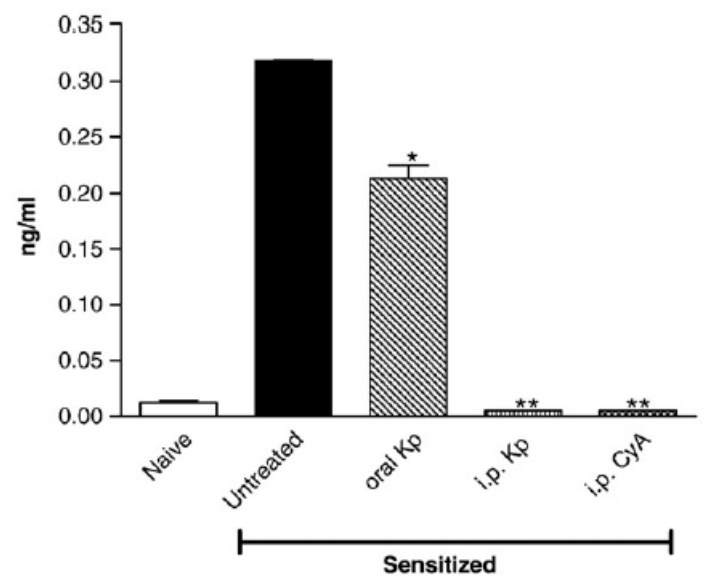

Fig. 7. Cytokine production in Kp-treated mice. Lymph nodes were obtained from mice that were sensitized and treated with $\mathrm{Kp}$ or Cyclosporin A (CyA) as indicated, and the cells restimulated in vitro with $1 \mathrm{mg} / \mathrm{ml}$ of OVA. After $48 \mathrm{~h}$, the culture supernatants were collected for the determination of IL-5, IL-10 and TNF- $\alpha$ levels by ELISA.Means \pm S.D. $(n=5)$. ${ }^{*} \mathrm{p} \leq 0.05$ and ${ }^{* *} \mathrm{p} \leq 0.01$ in relation to untreated controls. 


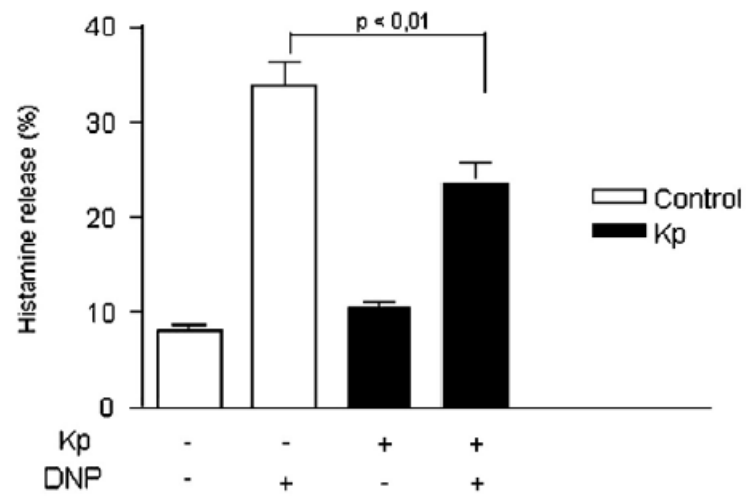

Fig. 8. Prevention of mast cell histamine release by Kp in vitro. Rat peritoneal mast cells were sensitized in vitro with anti-DNP IgE and then incubated with $500 \mu \mathrm{g} / \mathrm{ml}$ of Kp for 30 min prior to the 1-hour challenge with $50 \mu \mathrm{g} / \mathrm{ml}$ of DNP/BSA. Histamine was measured in the supernatants by a fluorimetric assay and expressed as the percentage of total histamine in cell lysates. Means \pm S.D $(n=4)$.

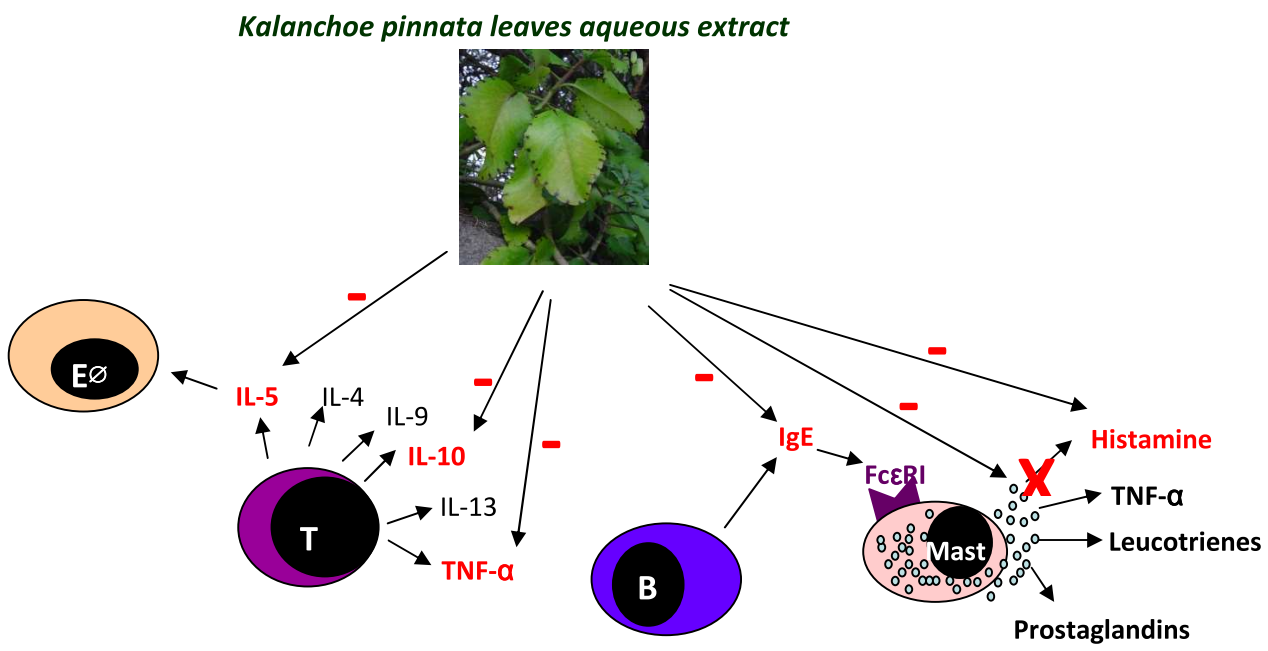

E申: eosinophil, B: B lymphocyte, TH2: TH2 lymphocyte, Mast: mast cell.

Fig. 9. Anti-anaphylactic mechanisms of Kp. Anaphylactic shock is mediated by immunological mechanisms involving the production of Th2 cytokines (IL-4, IL-5, IL-9 and IL-13), the production of antigen-specific IgE antibodies, the recruitment and activation of eosinophils (through IL-5) and mast cells. The subsequent contact with antigen causes crosslinking of IgE molecules that are linked to the surface of mast cells via Fce RI receptor and subsequent degranulation. After crosslinking, there is a systemic release of inflammatory mediators that responsible for the symptoms and the severity of anaphylaxis. Treatment with aqueous extract of $\mathrm{Kp}$ inhibits the production of IgE, the production of IL10 , IL- 5 and TNF- $\alpha$, degranulation of mast cells and histamine release. 
The safety of Kp to humans is substantiated by the fact that it is widely consumed in the popular medicine, and that a human case of cutaneous leishmaniasis displayed unaltered serum toxicological parameters following oral treatment (Torres-Santos et al, 2003). For its effectiveness in mice and expected clinical safeness, quercitrin-containing $\mathrm{Kp}$ or quercitrin alone are potential candidates for clinical tests aiming at a prophylactic therapy for hypersensitive people under the risk of anaphylactic shock.

Anaphylaxis is a life-threatening allergic condition. Promising preventive measures include allergen nonspecific and allergen-specific immunotherapy. A range of plant species, including Kalanchoe pinnata, contain promising anti-allergic substances. Flavonoids extracted from K. pinnata, particularly quercitrin that down regulate Th2-type immune responses and also inflammatory reactions primarily induced by TNF-a, that together lead to overt release of histamine and other mediators by mast cells and basophils, culminating with anaphylactic shock.

\section{References}

Akdis, C.A. \& Blaser, K. (2000). Mechanisms of allergen-specific immunotherapy. Allergy, 55, pp. (522-530).

Akinpelu, D.A. (2000). Antimicrobial activity of Bryophyllum pinnatum leaves. Fitoterapia, 71, pp. (193-194).

Allorge-Boiteau, L. (1996). Madagascar centre de spéciation et d'origine du genre Kalanchoe (Crassulaceae). In: Biogéographie de Madagascar. LOURENÇO, W.R. Editions de l'ORSTOM, Paris.

Almeida, A.P., Da Silva, A.G., Souza, M.L.M., Lima, L.M.T.R. Rossi-Bergmann, B., Gonçalves De Moraes, V.L. \& Costa, S.S. (2000). Isolation and chemical analysis of a fatty acid fraction of Kalanchoe pinnata with a potent lymphocyte suppressive activity. Planta Medica, 66, pp. (134-137).

Barua, C.C., Gupta, P.P., Patnaik, G.K., Kulshrestha, D.K. \& Dhawan, B.N. (1997). Studies on antianaphylactic activity of fractions of Albizzia lebbeck. Current Science, 72, 6, pp. (397-399).

Baruah, C.C., Gupta, P.P., Nath, A, Patnaik, L.G.K. \&; Dhawan, B.N. (1998). Anti-allergic and anti-anaphylactic activity of picroliv - A standardised iridoid glycoside fraction of Picrorhiza kurroa. Pharmacological Research, 38, 6, pp. (487-492).

Chandrashekhara, V.M., Halagalia, K.S., Nidavania, R.B., Shalavadia, M.H., Ganapatyb, S., Biswasa, D. \& Muchchandia, V.M. (2011). Anti-allergic activity of German chamomile (Matricaria recutita L.) in mast cell mediated allergy model. Journal of Ethnopharmacology, 137, 1, pp. (336-340).

Comalada, M., Ballester, I., Bailón, E., Sierra, S., Xaus, J., Gálvez, J., De Medina, F.S. \& Zarzuelo, A. (2006). Inhibition of pro-inflammatory markers in primary bone marrow-derived mouse macrophages by naturally occurring flavonoids: Analysis of the structure-activity relationship. Biochemical Pharmacology, 72, pp. (1010-1021).

Costa, S.S., Muzitano, M.F., Camargo, L.M.M. \& Coutinho, M.A.S. (2008). Therapeutic Potential of Kalanchoe Species: Flavonoids and other Secondary Metabolites. Natural Product Communications, 3, pp. (2151-2164).

Cruz, E.A., Da-Silva, S.A.G, Muzitano, M.F., E Silva, P.M.R., Costa, S.S. \& Rossi-Bergmann, B. (2008). Immunomodulatory Immunomodulatory pretreatment with Kalanchoe 
pinnata extract and its quercitrin flavonoid effectively protects mice against fatal anaphylactic shock. International Immunopharmacology, 8, 12, pp. (1616-1621).

Cruz, E.A., Reuter, S., Martin, H., Dehzad, N., Muzitano, M.F., Costa, S.S., Rossi-Bergmann, B., Buhl, R., Stassen, M. \& Taube, C. (2011). Kalanchoe pinnata inhibits mast cell activation and prevents allergic airway disease. Phytomedicine. (Jul 2011).

Da-Silva, S.A.G., Costa, S.S., Mendonça, S.C.F., Silva, E.M., Moraes, V.L.G. \& RossiBergmann B. (1995). Therapeutic effect of oral Kalanchoe pinnata leaf extract in murine leishmaniasis. Acta Tropica, 60, pp. (201-210).

Da-Silva, S.A.G., Costa, S.S. \& Rossi-Bergmann, B. (1999). The anti-leishmanial effect of Kalanchoe is mediated by nitric oxide intermediates. Parasitology, 118, pp. (575-582).

Farnsworth, N.R. (1994). Ethnopharmacology and drug development. Ciba Foundation Symptoms, 185, pp. (42-51).

Francis, J.N., Till, S.J. \& Durham, S.R. (2003). Induction of IL-10+CD4+CD25+ T cells by grass pollen immunotherapy. J. Allergy Clin. Immunology, 111, pp. (1255-1261).

Fukumoto, H., Yamaki, M., Isoi, K. \& Ishiguro, K. (1996). Antianaphylactic effects of the principal compounds from the white petals of Impatiens balsamina L. Phytotherapy Research, 10, 3, pp. (202-206).

Gaind, K.N. \& Gupta, R.L. (1972). Alkanes, alkanols, triterpenes and sterols of Kalanchoe pinnata. Phytochemistry, 11, pp. (1500-1502).

Gaind, K.N. \& Gupta, R.L. Flavonoid glycosides from Kalanchoe pinnata. (1971). Planta Medica, 20, pp. (368-373).

Ghaisas, M.M., Kumar, D., Sarda, A.P. \& Bhamre, S.S. (2011). Anti-anaphylactic and Mast Cell Stabilizing Effect of Calotropis gigantea Extract. Latin American Journal of Pharmacy, 30, 2, pp. (363-367).

Gomes, D.C.O., Muzitano, M.F., Costa, S.S. \& Rossi-Bergmann, B. (2009). Effectiveness of the immunomodulatory extract of Kalanchoe pinnata against murine visceral leishmaniasis. Parasitology, 137, pp. (613-618).

Ichikawa, M., Ogura, M. \& Iijima, T. Antiallergic flavone glycoside from Kalanchoe pinnatum. Patent 61, 118, 396 [86, 118, 319] (Cl. CO7H17/07), Apl 84/240, 282, 14 nov 1984; 4pChemical Abstracts, 105, 178423q, 1986.

Ishiguro, K. \& Fukumoto, H. (1997). A practical and speedy screening method for murine anaphylaxis: On the antianaphylactic effect of Impatiens balsamina L. Phytotherapy Research, 11, 1, pp. (48-50).

Jeong, H.J., Lee, S.A., Moon, P.D., Na, H.J., Park, R.K., Um, J.Y., Kim, H.M. \& Hong, S.H. (2006). Alginic acid has anti-anaphylactic effects and inhibits inflammatory cytokine expression via suppression of nuclear factor-kappa B activation. Clinical and Experimental Allergy, 36, 6, pp. (785-794).

Jutel, M., Akdis, M., Budak, F., Aebischer-Casaulta, C., Wrzyszcz, M., Blaser, K. \& Akdis, C.A. (2003). IL-10 and TGF-beta cooperate in the regulatory $\mathrm{T}$ cell response to mucosal allergens in normal immunity and specific immunotherapy. European Journal of Immunology, 33, pp. (1205-1214).

Kang, T.H., Choi, I.Y., Kim, S.J., Moon, P.D., Seo, J.U., Kim, J.J., An, N.H., Kim, S.H., Kim, M.H., Um, J.Y., Hong, S.H., Kim, H.M. \& Jeong, H.J. (2010). Ailanthus altissima swingle has anti-anaphylactic effect and inhibits inflammatory cytokine expression via suppression of nuclear factor-kappaB activation. In Vitro Cellular $\mathcal{E}$ Developmental Biology-Animal, 46, 1, pp. (72-81). 
Kawai, M., Hirano, T., Higa, S., Arimitsu, J., Maruta, M., Kuwahara, Y., Ohkawara, T., Hagihara, K., Yamadori, T., Shima, Y., Ogata, A., Kawase, I. \& Tanaka, T. (2007). Flavonoids and Related Compoundsas Anti-Allergic Substances. Allergology International, 56, pp. (113-123).

Kemp, S.F., Lockey, R.F. \& Simons, F.E.R. (2008). Epinephrine: the drug of choice for anaphylaxis: a statement of the World Allergy Organization. Allergy, 63, pp. (10611070).

Kemp, S.F. \& Lockey, R.F. (2002). Anaphylaxis: A review of causes and mechanisms. Journal of Allergy and Clinical Immunology, 110, pp. (341-348).

Kim, H.M., Yi, D.K. \& Shin, H.Y. (1999). The evaluation of antianaphylactic effect of Oryza sativa L-in rats. American Journal of Chinese Medicine, 27, 1, pp. (63-72).

Kim, S.H., Park, H.H., Lee, S., Jun, C.D., Choi, B.J., Kim, S.Y., Kim, S.H., Kim, D.K., Park, J.S., Chae, B.S. \& Shin, T.Y. (2005). The anti-anaphylactic effect of the gall of Rhus javanica is mediated through inhibition of histamine release and inflammatory cytokine secretion. International Immunopharmacology, 5, 13-14, pp. (1820-1829).

Lee, J.H., Kim, J.W., Ko, N.Y., Mun, S.H., Kim, D,K., Kim, J.D., Kim, H.S. Lee, K.R., Kim, Y.K., Radinger, M., Her, E. \& Choi, W.S. (2008). Camellia japonica suppresses immunoglobulin E-mediated allergic response by the inhibition of Syk kinase activation in mast cells. Clinical and Experimental Allergy, 38, 5, pp. (794-804).

Lee, Y.M., Kim, D.K., Kim, S.H., Shin, T.Y. \& Kim, H.M. (1996). Antianaphylactic activity of Poncirus trifoliata fruit extract. Journal of Ethnopharmacology, 54, 2-3, pp. (77-84).

Li, X.M. \& Brown, L. (2009). Efficacy and mechanisms of action of traditional Chinese medicines for treating asthma and allergy. Journal of Allergy and Clinical Immunology, 123, pp. (297-306).

Li, X.M., Zhang, T.F., Sampson, H., Zou, Z.M., Beyer, K., Wen, M.C. \& Schofield, B. (2004). The potential use of Chinese herbal medicines in treating allergic asthma. Annals of Allergy, Asthma and Immunology, 93, PP. (S35-S44).

Lorenzi, H. \& Abreu-Matos, F.J. (2008). Plantas Medicinais no Brasil - nativas e exóticas, (2a ed), Instituto Plantarum de Estudos da Flora Ltda, São Paulo, Brasil.

Lucas, V. \& Machado, O. (1946). Contribuição ao estudo das plantas medicinais brasileiras Saião. Revista da Flora Medicinal, 77, PP. (1-39).

Muñoz, V., Sauvain, M., Bourdy, G., Callapa, J., Rojas, I., Vargas, L. \& Deharo, E. (2000). The search for natural bioactive compounds through a multidisciplinar approach in Bolivia: Part II. Antimalarial activity of some plants used by mosetane Indians. Journal of Ethnopharmacology, 69, pp. (139-155).

Muzitano, M.F., Cruz, E.A., Almeida, A.P., Da Silva, S.A., Kaiser, C.R., Guette, C., RossiBergmann, B. \& Costa, S.S. (2006a). Quercitrin: an antileishmanial flavonoid glycoside from Kalanchoe pinnata. Planta Medica, 72, pp. (81-83).

Muzitano, M.F., Tinoco, L.W., Guette, C., Kaiser, C.R., Rossi-Bergmann, B. \& Costa, S.S. (2006b). Assessment of antileishmanial activity of new and unusual flavonoids from Kalanchoe pinnata. Phytochemistry, 67, pp. (2071-2077).

Muzitano, M.F., Bergonzi M.C., De Melo, G.O., Lage, C.L.S., Bilia A.R., Vincieri F.F., RossiBergmann, B. \& Costa, S.S. (2011). Influence of cultivation conditions, season of collection and extraction method on the content of antileishmanial flavonoids from Kalanchoe pinnata. Journal of Ethnopharmacology, 133, pp. (132-137). 
Muzitano, M.F., Falcão, C.A.B., Cruz, E.A., Bergonzi M.C., Bilia A.R., Vincieri F.F., RossiBergmann, B. \& Costa, S.S. (2009). Oral Metabolism and Efficacy of Flavonoids in a Murine Model of Cutaneous Leishmaniasis. Planta Medica, 75, pp. (307-311).

Nakamura, R., Nakamura, R., Watanabe, K., Oka, K., Ohta, S., Mishima, S. \& Teshima, R. (2010). Effects of propolis from different areas on mast cell degranulation and identification of the effective components in propolis. International Immunopharmacology, 10, pp. (1107-1112).

Nassis, C. Z., Haebisch, E.M. \& Giesbrecht, A.M. (1992). Antihistamine activity of Bryophyllum calycinum. Brazilian Journalof Biological Research, 25, pp. (929-936).

Neves, J.S., Coelho, L.P., Cordeiro, R.S.B., Veloso, M.P., Silva, P.M.R.E, Dos Santos, M.H. \& Martins, M.A. (2007). Antianaphylactic properties of 7-epiclusianone, a tetraprenylated benzophenone isolated from Garcinia brasiliensis. Planta Medica, 73, 7, pp. (644-649).

Newman, D.J. \& Cragg, G.M. (2007). Natural products as sources of new drugs over the last 25 years. Journal of Natural Products, 70, pp. (461-477).

Okpo, S.O. \& Adeyemi, O.O. (2002). The antianaphylactic effects of Crinum glaucum aqueous extract. Journal of Ethnopharmacology, 81, 2, pp. (187-190).

Plangger, N., Rist, L., Zimmermann, R. \& Von Mandach, U. (2006). Intravenous tocolysis with Bryophyllum pinnatum is better tolerated than beta-agonist application. European Journal of Obstetrics \& Gynecology and Reproductive Biology, 124, pp. (168172).

Rossi-Bergmann, B., Costa, S.S., Borges, M.B.S., Da-Silva, S.A., Noleto, G.R., Souza, M.L.M \& Moraes, V.L.G. (1994). Immunosuppressive effect of the aqueous extract of Kalanchoe pinnata in mice. Phytotherapy Research, 8, pp. (399-402).

Sforcin, J.M. (2007). Propolis and the immune system: a review. Journal of Ethnopharmacology, 113, pp. (1-14).

Shams, K.A. \& Schmidt, R. (2007). Lipid fraction constituents and evaluation of antianaphylactic activity of Prunus mahaleb L. kernels. African Journal of Traditional Complementary and Alternative Medicines, 4, 3, pp. (289-293).

Siddiqui, S., Fazi, B.S. \& Sultana, N. (1989). Triterpenoids and phenanthrenes from leaves of Bryophullum pinnatum. Phytochemistry, 28, pp. (2433-2438).

Sousa, P.J.C., Rocha, J.C.S., Pessoa, A.M., Alves, L.A.D. \& Carvalho, J.C.T. (2005). Estudo preliminar da atividade antiinflamatória de Bryophillum calycinum Salisb. Revista Brasileira de Farmacognosia, 15, pp. (60-64).

Supratman, U., Fujita, T., Akiyama, K., Hayashi, H., Murakami, A., Sakai, H., Koshimizu, K. \& Ohigashi, H. (2001). Anti-tumor promoting activity of bufadienolides from Kalanchoe pinnata and K. daigremontiana X tubiflora. Bioscience Biotechnology and Biochemistry, 65, 4, pp. (947-949).

Torres-Santos, E.C., Da-Silva, S.A.G, Santos, A.P.P.T., Almeida, A.P., Costa, S.S. \&, RossiBergmann, B. (2003). Toxicological analysis and effectiveness of oral Kalanchoe pinnata on a human case of leishmaniasis. Phytotherapy Research 17, pp. (801-803).

Ueda, Y., Oku, H., Iinuma, M. \& Ishiguro, K. (2005). Antianaphylactic and antipruritic effects of the flowers of Impatiens textori MiQ. Biological \& Pharmaceutical Bulletin, 28, 9, pp. (1786-1790). 
Venkatesh, P., Mukherjee, P.K., Mukherjee, D., Bandyopadhyay, A., Fukui, H. \& Mizuguchi, H. (2010). Potential of Baliospermum montanum against compound 48/80-induced systemic anaphylaxis. Pharmaceutical Biology, 48, 11, pp. (1213-1217).

Westfall, T.C. \& Westfall, D.P. (2006). Adrenergic agonists and antagonists, In: Goodman $\mathcal{E}$ gilman's the basis of pharmacological therapeutics. Brunton, L.L., Lazo, J.S., Parker, K.L., (11a ed.), pp. (237-295), McGraw-Hill, New York.

Yadav, N.P. \& Dixit, V.K. (2003). Hepatoprotective activity of leaves of Kalanchoe pinnata Pers. Journal of Ethnopharmacology, 86, 2-3, pp. (197-202).

Yamagishi, T., Haruna, M., Yan, X.Z., Chang, J.J. \& Lee, K.H. (1989). Antitumor agents, 110 1,2, Bryophilin B, a novel potent cytotoxic bufadienolide from Bryophullum pinnatum. Journal of Natural Products, 52, pp. (1071-1079).

Youssouf, M.S., Kaiser, P., Tahir, M., Singh, G.D., Singh, S., Shanna, V.K., Satti, N.K., Haque, S.E. \& Johri, R.K. (2007). Anti-anaphylactic effect of Euphorbia hirta. Fitoterapia, 7-8, pp. (535-539). 


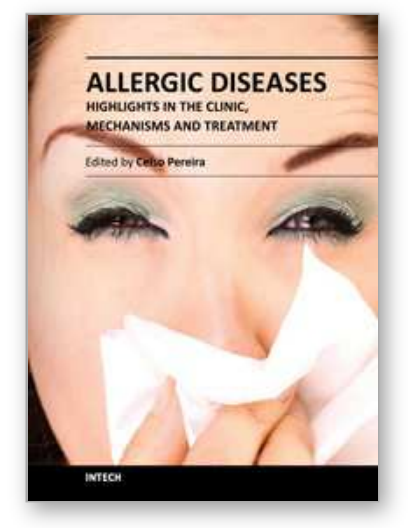

\author{
Allergic Diseases - Highlights in the Clinic, Mechanisms and \\ Treatment \\ Edited by Prof. Celso Pereira
}

ISBN 978-953-51-0227-4

Hard cover, 554 pages

Publisher InTech

Published online 14, March, 2012

Published in print edition March, 2012

The present Edition "Allergic diseases - highlights in the clinic, mechanisms and treatment" aims to present some recent aspects related to one of the most prevalent daily clinical expression disease. The effort of a group of outstanding experts from many countries reflects a set of scientific studies very promising for a better clinical care and also to the treatment and control of the allergy. This book provides a valuable reference text in several topics of the clinical allergy and basic issues related to the immune system response. The inflammatory reaction understanding in allergic disease is clearly evidenced, as well as new strategies for further researches.

\title{
How to reference
}

In order to correctly reference this scholarly work, feel free to copy and paste the following:

Elaine A. Cruz, Michelle F. Muzitano, Sonia S. Costa and Bartira Rossi-Bergmann (2012). Preventive Phytotherapy of Anaphylaxis and Allergic Reactions[MSOffice1], Allergic Diseases - Highlights in the Clinic, Mechanisms and Treatment, Prof. Celso Pereira (Ed.), ISBN: 978-953-51-0227-4, InTech, Available from: http://www.intechopen.com/books/allergic-diseases-highlights-in-the-clinic-mechanisms-andtreatment/preventive-phytotherapy-of-anaphylactic-shock

\section{INTECH}

open science | open minds

\author{
InTech Europe \\ University Campus STeP Ri \\ Slavka Krautzeka 83/A \\ 51000 Rijeka, Croatia \\ Phone: +385 (51) 770447 \\ Fax: +385 (51) 686166 \\ www.intechopen.com
}

\author{
InTech China \\ Unit 405, Office Block, Hotel Equatorial Shanghai \\ No.65, Yan An Road (West), Shanghai, 200040, China \\ 中国上海市延安西路65号上海国际贵都大饭店办公楼 405 单元 \\ Phone: +86-21-62489820 \\ Fax: +86-21-62489821
}


(C) 2012 The Author(s). Licensee IntechOpen. This is an open access article distributed under the terms of the Creative Commons Attribution 3.0 License, which permits unrestricted use, distribution, and reproduction in any medium, provided the original work is properly cited. 